\title{
COMPETITION IN THE ADVANCED SALE OF SERVICE CAPACITY
}

$\mathrm{Ng}$, Irene C.L.

Lee, Khai Sheang

March 6, 2008

Irene $\mathrm{C} \mathrm{L} \mathrm{Ng}$ is an Associate Professor of Marketing at the School of Business and Economics, University of Exeter (U.K.). Contact Information: School of Business and Economics, University of Exeter, Streatham Court, Rennes Drive, Exeter EX4 4PU, United Kingdom Tel: +44 (0) 1392 263250, Fax: +44 (0) 1392 263242, Email:

Irene.Ng@exeter.ac.uk

Khai-Sheang Lee is an Associate Professor with the Department of Marketing, Faculty of Business Administration, National University of Singapore, National University of Singapore, 10 Kent Ridge Crescent, Tel: (65) 6516-3163, Fax: (65) 6776 3467, Email: bizleeks@nus.edu.sg 


\title{
COMPETITION IN THE ADVANCED SALE OF SERVICE CAPACITY
}

\begin{abstract}
Since service production and consumption are inseparable, many service firms sell their capacity in advance. Consequently, the question is whether it is optimal to sell more or less in advance, and if so, at what price and quantity. This paper examines the optimality and practice of advanced sale of service capacity under duopolistic competition.

Using a game theoretic approach, the paper provides a possible explanation as to why, despite sophisticated practices of advanced sale in many service industries, there are still many other service firms that commonly do not sell in advance. It demonstrates that competition and market price sensitivity to a firm's capacity are two factors that can impact not only on a firm's decision to sell in advance, but on its pricing and capacity allocation decisions as well.
\end{abstract}

Keywords: services; yield management; competitive strategy; game theory; advanced sale; capacity 


\section{Biographical Notes}

Dr Irene $\mathrm{Ng}$ is an Associate Professor at the School of Business \& Economics, University of Exeter, United Kingdom. She is also the founder and director of the Centre for Service Research as well as the Head of Postgraduate Studies of the school. Dr. Ng comes from 15 years of practice and was the CEO of SA Tours, one of the largest tour operators in Malaysia and Singapore, Founder and CEO of Empress Cruise Lines and subsequently the Group Vice Chairman of the SA Tourism group from the period of $1988-2003$.

Dr Khai S. Lee is an Associate Professor at the National University of Singapore Business School. He specializes in competitive strategy, and his research interest is in the area of game yheory and business strategy. The latter includes the application of game theory to marketing Mix (4Ps) strategies, industrial marketing strategies, competitive Strategies, marketing of credence products, entrepreneurship and small business strategies, and channel management strategies. He is the main author of the book, "Competing for Markets: Growth Strategies for SMEs" (2002) and also a pioneer on the application of Sun Tzu's Art of War to business co-authoring the book: "Sun Tzu: War and Management" (1991) - a first in the area. 


\section{COMPETITION IN THE ADVANCED SALE OF SERVICE CAPACITY}

\section{INTRODUCTION}

The very act of creating a service for a customer requires the source to be present, either as man or machine. This means that the production and consumption of a service is simultaneous, as it is widely established (Zeithaml, 2006; Bruhn \& Goergi, 2006; Kasper et al, 2006). Consequently, any sale of a service is essentially a form of advanced sale prior to production, even though the time in advance may be mere minutes, as in the purchase of a movie ticket (cf. Edgett and Parkinson, 1993). This is in contrast to goods, where most goods firms retain a choice of whether to sell before or after production.

The pressure of a service firm to practice advanced selling further in advance of consumption is made more compelling considering that the inseparability of production of consumption is double edged. Not only is the firm not able to produce and store the service in advance, the customer is also not able to store the service in advance of consumption. Thus, he faces the uncertainty that the service may not be available to him when he requires it, especially if the service firm has limited capacity (Biyalogorsky \& Gerstner, 2004; Ng, 2007). To alleviate that risk, he may be willing to purchase further in advance of consumption, as insurance (Png, 1989).

Accordingly, it would be logical to assume that there would exist some demand at a time considerably in advance of production/consumption of a service. It is therefore a question of whether it is optimal to sell more or less considerably in advance, and if so, at what price and quantity. Seen in this context, advanced selling therefore becomes a marketing problem. 
Our study focuses on the advanced sale of services. Specifically, we study how to price and how much capacity to allocate in advance, and at the time of consumption of a service. As research into advanced selling is still in its early stages in marketing literature, we would first provide some background to its practices well as the related research in this area.

Many service firms practice advance selling as a norm, with some services being sold more than 6 months ahead of production/consumption, such as airline seats, hotel rooms and cruises. There are many diverse reasons why firms sell in advance. In the case of Eurotunnel (the operator of the Channel Tunnel), advanced selling is done for cash flow reasons, to maximise cash revenues so as to ease the burden of paying interests on huge loans (Anon, 1994). In the TV syndication industry, lower ratings that resulted from an oversupply of action/adventure cartoons, prompted TV syndicates to advance sell an alternative softer animated series, in 1987 , in order to pre-empt competition. In the trade show industry, advanced sale is conducted to ease planning, and for efficiency reasons (Pridmore, 1987). For the same reason, advanced sale (or "upfront" selling as it is termed sometimes) is also undertaken in the TV advertising industry. Through advanced selling, the early monetary commitments by advertisers allows TV networks to plan their promotions budget based on committed revenues, to ensure that their shows achieve the promised ratings (Walley, 1990). Additionally, firms advance sell to produce greater revenue in advance periods for customers who face uncertainty about future valuations. This practice is most common for firms who are assured about demand patterns in their business cycle (Shugan \& Xie, 2004). 
However, despite the practice in some industries to advance sell, the optimality of advanced selling is not unequivocal among industry members. Within the academic community, especially in marketing, this phenomenon has yet to be critically investigated. Only recently has this phenomenon been illuminated and examined (see Desiraju and Shugan, 1999; Shugan and Xie, 2000, 2004, 2005). Most notably, Shugan and Xie highlighted the superiority of advanced selling and how it offers an opportunity for higher profits.

Although advanced selling itself has not been scrupulously examined, one stream of academic literature has accepted it as a practice. This first stream considers advanced sale necessary to ensure a match between supply and demand of a service at the time of consumption (Sasser, 1976; Shemwell \& Cronin, 1994; Harris and Peacock, 1995). Since service firms often operate with fixed capacities that are predetermined before the onset of demand (Berry, Zeithaml and Parasuraman, 1984; Ng, Wirtz and Lee, 1999), matching the supply of service capacity to demand is a challenging task, especially when demand is uncertain. Yet, the matching of supply and demand is important for service firms because services are perishable (Desiraju and Shugan, 1999; Lee and $\mathrm{Ng}, 2000$; $\mathrm{Ng}$, Wirtz and Lee, 1999), and hence any unsold capacity is not recoverable after the date of consumption. Through advanced sale, studies in this stream propose that firms create new demand during off-peak periods (Weatherford and Pfeifer, 1994) or level out the peaks by moving customers to other non-peak times (Iyer et al, 2003; Dana, 1999 \& 1998; Bateson, 1985). This can be done through time-based price discrimination, charging lower prices for the use of off-peak capacity and higher otherwise (Nagle \& Holden, 
1995). Although the issues investigated in this stream of literature are important, there is a lack of literature into how much capacity should be sold in advance and at what price.

Closely related to this stream is another second stream of academic literature from the decision sciences. Research in this area proposes that customers purchase at different times in advance of consumption i.e. some arrive early and some arrive later (closer to consumption date). The challenge to the firm is how to optimise revenue by pricing and/or setting capacities to be sold at each point in advance, taking into account the arrival times of the customers. Commonly labeled as yield or revenue management, such practices have successfully increased the revenues of service firms through the increasing use of sophisticated and computerised yield management systems (Kimes, 2000, Talluri et al, 2006). For example, since the USA deregulated the airline industry in 1978, many airlines report increases in revenue of five (5) percent or more after starting a yield management programme (Lloyds, 1985, Kimes, 1989). In a 1998 report, it was reported that American Airlines' yield management system (YMS) generated close to \$1 billion of incremental revenue per annum (Cook, 1998). Similarly, Chase (1999) states that firms who invest in revenue management systems have seen their revenues increase by as much as $7 \%$ with minimum capital outlay resulting in $50 \%-100 \%$ increase in profits. With newer technology and powerful programming, we find increasing service firms relying on YMS to assist with optimizing revenue. Therefore it is not surprising that retailers were reported to have spent about $\$ 30$ billion for the year 2001 improving their IT capabilities in order to compete more effectively in the world of revenue management (Raman et al, 2001). Since then, academic literature on revenue management have also grown extensively. 
However, with few exceptions, current understanding of revenue management is largely on a computational and operational level, with literature dominated by the field of operations management. Thus, most of the studies often focus on optimisation rather than marketing issues $(\mathrm{Ng}, 2007)$. Strategic interactions between a firm and its customers have also been largely ignored. In addition, existing research is mainly concerned with monopolistic situations.

The difference between the first and the second stream of research is explained as follows. The first stream deals with selling a service in advance (and thus influencing demand) for consumption at various times that a service is offered, commonly labelled as de-marketing. The second addresses the issue of selling in advance a service that is to be consumed at one specified time. To illustrate the distinction, a hotel room on the Friday night of a long weekend is greatly sought after, compared to the same hotel room the day before. The first stream deals with how to level demand, through advanced sale, for that Friday night, such that any excess demand can be pushed to other nights. The second addresses the issue of how to price Friday night's room in advance, according to the different purchase times of the customers. In other words, while both streams deal with price discrimination based on time; the first stream discriminates on time of use whilst the second discriminates on the time of purchase.

Our work is more relevant to the second stream and accordingly, to the extensive literature on revenue management. However, even though we also investigate the price/capacity allocation problem, ours differ in a number of important ways.

First, we maintain that it is not sufficient to examine revenue management as an operational or optimisation issue. Since revenue management fundamentally brings in the 
pricing behaviour of firms, concepts of consumer behaviour should be incorporated. Accordingly, we incorporate the use of a demand function in our model and investigate the market price sensitivity to capacity. In doing so, we aim to provide a deeper understanding of advanced sale at a theoretical level. To our knowledge, it is the first time any such investigation has been conducted. Thus, we have kept the model simple and free of abstractions and suggest a perspective for future research in this area.

Second, our study does not pre-suppose the optimality of advanced sale. In so doing, our study uncovers another reason why a service firm may want to sell in advance. When a firm sells part of its capacity in advance, the contraction in the overall capacity available pushes prices up at the time of consumption, increasing overall profits. In light of this, advanced sale does not necessarily require demand at the point of consumption/production to be uncertain. We also show that, under certain conditions, it may not be optimal for a firm to sell in advance but sell only close to the time of consumption.

Third, we also examine how competition impacts the capacity allocations in advance, and the optimality of such a practice, from an economic perspective, following a game theoretic approach.

Our study presents a model of advanced sale, in which the competing firms choose simultaneously, in Cournot (1838) style, their capacity allocations for advanced sale. This is followed by their choice, simultaneously, of capacity allocations for sale at the time of consumption. In our model, prices are endogenous on the capacity allocations of the firms. We examine the cases when the firms' response functions are symmetric 
and when they are asymmetric, which capture the situations when the firms are identical and differentiated respectively.

Although one would expect that firms would react to competition by selling more in advance, we show that competition results in a reduction of the total capacities allocated for advanced sale. The proportion of a firm's total capacity allocated for advanced sale is also reduced, when faced with competition. This is because of the interactions of several market forces. While competitive pressure may drive the firms to sell in advance to avoid the risk of losing sales to the competitor, the reduced profit margins for advanced sale causes them to decrease their capacity allocations for sale at that time. On the other hand, while higher profit margins at the time of consumption induces the firms to increase capacity allocations for sale at that time, the price sensitivity of the market prevents the firms from allocating excessive capacities for sale at that time.

Competition also results in a firm, whose response function is more pricesensitive, allocating less capacity for both advanced sale and sale at the time of consumption. This is because, for a firm whose response function is more pricesensitive, an increase in capacity allocations in both times of sale reduces its prices more than those of a firm whose response function is less price-sensitive. Indeed, the ratio of a firm's capacity allocation for advanced sale to its allocation for sale at the time of consumption decreases with increased price sensitivity of the market to its capacity supplies. As its response function becomes increasingly price sensitive, the firm's capacity allocation for advanced sale approaches zero. In the next section, a review of relevant literature is presented, followed by the specification of the model. 


\section{LITERATURE REVIEW}

As advanced sale has not, until only very recently, been thought of as a marketing phenomenon, the literature in this field has been greatly dominated by the operations management research. We now present a review of the relevant studies.

The objective of revenue management studies is to maximise yield by managing the sale of service capacity over time, through pricing, capacity allocation, and timing of sale (Desiraju \& Shugan, 1999, Chase, 1999, Kimes, 2000, Boyd \& Bilegan, 2003). Very broadly, research in this area can be further categorised into two streams. The first stream focuses on the pricing of service capacity over time, to maximise yield (e.g. see Bitran \& Caldentey, 2003, Orkin, 1988 for a review of such practices). For example, several studies have examined how a firm should price over time, given a demand profile forecast (Elmaghraby \& Keskinock, 2003, Fleischmann et al, 2004, Burger \& Fuchs, 2005), and given information updates when the demand profile is stochastic (Pfeifer, 1989). Chiang et al (2007) provides a comprehensive review of revenue management practices.

The second stream of yield management research focuses on a firm's reservation policies, which include booking and overbooking policies - i.e. confirming reservations from customers in excess of available service capacity. For example, various authors have examined how firms could insure themselves against no-shows or cancellations by consumers, through appropriate reservation policies and inventory optimisation (Bertsimas \& Popescu, 2003; Pak \& Piersma, 2002; McGill \& Van Ryszin, 1999). Early researchers in this area including Alstrup et al. (1986), Belobaba (1989), Hersh and Ladany (1978), Ladany (1976), Lieberman and Yechiali (1978), Pfeifer (1989), Rothstein 
(1971, 1974, 1985), Thompson (1961) and Toh (1985) have also examined the pricing implications associated with such policies.

In the majority of these studies, the yield management problem is structured as one in which firms maximise payoffs/yield, given some forecasted demand profile (e.g. Badinelli and Olsen, 1990; Belobaba, 1989; Bodily and Weatherford, 1995; Hersh and Ladany, 1978; Pfeifer, 1989; Toh, 1979). Over time, increasingly complex demand profiles, which require increasingly sophisticated mathematical procedures or algorithms to obtain solutions, have been introduced and investigated (e.g. Feng \& Xiao, 2000, 2001, 2006; Bertsimas \& Boer, 2005; Weatherford \& Polt, 2002; Pak \& Peirsma, 2002; Brumelle \& Walczak, 2003). For the purpose of this paper, we have chosen not to review the methods employed by the studies in operations research as the mathematical focus of these studies have little relevance to the issues investigated in our study. It has to be noted though, that with a few exceptions (i.e. Desiraju and Shugan, 1999; Lee and Ng, 2000; Png, 1989, 1991; Shugan and Xie, 2000; Xie and Shugan, 2001), current understanding of yield management is largely on a computational and operational level with little regard for economic and marketing theories (Desiraju and Shugan, 1999; Ng, 2007). In addition, other than the studies by Png (1989, 1991), Desiraju and Shugan (1999), Shugan and Xie (2000), and Xie and Shugan (2001), current research does not examine explicitly the strategic interactions between a firm and its customers. Instead, yield management systems (YMS) in general assume an exogenous demand profile, and hence ignore the potential impact of a firm's actions (specifically capacity allocations) on the demand profile. What is more, existing studies have also overlooked the strategic 
interactions between competing firms and how such interactions may impact the firms' strategies in advanced sale (Shugan \& Xie, $2004 \&$ 2005; Williams, 1999).

Recognising these limitations, some researchers have suggested that a more thorough understanding of advanced sale at a conceptual level is required, and that the demand characteristics, upon which revenue management studies are premised, be based on fundamental concepts of consumer behaviour (Chase, 1999; Lieberman, 1993; Relihan, 1989). Consistent with such views, there are few studies that have been conducted. For example, Png (1989) examined the advanced sale of service capacity when consumers are risk-averse, and suggested that such consumers purchase in advance as an insurance against the uncertainty of service availability. $\mathrm{Ng}$ (2007) termed these phenomena as the valuation risk or an the acquisition risk of the customer. Valuation risk depends on the consumers' willingness to pay for a service in advance while facing uncertainty of consumption while acquisition risk is associated with the consumer's willingness to pay for a service in advance to guarantee the future availability of the service. Given that this is so, firms can therefore maximise their profits by selling in advance and charging a price premium for advanced sale, whilst discounting prices as the date of consumption approaches (Png, 1991). A study by Desiraju and Shugan (1999) examined the conditions for the use of yield management systems vis-à-vis more simplified pricing systems. Shugan and Xie (2000, 2004, 2005) also examined how profits can be improved by advanced sale. In that study, the authors explore the separation of consumption and advanced purchase for services and how such a separation can provide a price discrimination opportunity to increase profits. More recently, Xie and Shugan $(2001,2004,2005)$ provide an extensive paper on when and how firms should 
advance sell while Lee and $\mathrm{Ng}$ (2001) investigated the impact of price sensitivity on pricing and capacity allocations in advanced sale. In contrast to Png's (1991) result, Lee and $\mathrm{Ng}$ showed that price discounting in advanced sale is optimal when consumers' price sensitivity is taken into account. The study also showed that while it is commonly believed that advance selling stems from demand uncertainty at time of consumption, or is motivated by competitive pre-emption (McKenna, 1989), the findings show that even when uncertainty is absent, advanced selling is optimal. This is because when no advanced sale is undertaken the large amount of capacity available at the point of consumption drives prices down. However, with advanced sale, the capacity that is sold in advance (even though at a lower price) serves to reduce the capacity availability at the time of consumption, thus driving prices up at that time. The overall effect is that capacity utilisation is improved, and profits are increased. Anjos et. al. (2005) similarly showed that under certain assumptions about customers' price sensitivity, the prices charged should increase as the consumption date approaches.

This study provides an explanation for the practice of advance selling of TV advertising slots in the USA, as reported earlier. TV networks typically sell $75 \%-80 \%$ of their season's advertisement capacity months before the advertisements are aired. The remaining capacity is held back for quarterly "scatter" markets, where prices are much higher because there is less capacity available to meet demand (Mandese, 1995).

This paper extends Lee and Ng's study to examine how competition impacts advanced sale of service capacity. This is in contrast to existing studies, which are mainly concerned with monopolistic situations. Similar to Png's study $(1989,1991)$, we examine the optimality of advanced sale from an economic perspective, following a game 
theoretic approach. In terms of model structure, ours differs from that of Png's (1989, 1991) and Desaraju and Shugan's (1999) in significant ways. Compared to Desiraju and Shugan's (1999) model, which assumes a two-segment market, our formulation is based on a Cournot (1838)-type response function that captures the price-volume relationship for a given market. This is important for "understanding the impact of changing prices on the demand for a product or service" (Montgomery, 1988, p. 53). Doing so, we are also able to investigate how asymmetric price sensitivities impact the firms' decisions in competition

Firms in our model compete by choosing capacity allocations for advanced sale and for sale at the time of consumption. We do not place any restrictions on demand, as we are also interested in examining the impact of advanced sale on capacity utilisation. This is in contrast to Png's (1991) model, which assumes that demand outstrips capacity; hence the issue of excess capacity does not arise. Our study also differs from those that examine pricing strategies (e.g. peak load pricing or similar techniques) that aim to influence demand across time (or service delivery/consumption dates) to improve demand-supply match (e.g. Dana, 1999; Nagle \& Holden, 1995; Radas, 1998). While the focus of these studies is on pricing for multiple service delivery/consumption dates, our focus is on pricing for a single particular service delivery/consumption date that is sold at different times.

The rest of the paper is organised as follows. We present our model formulation in $\S 3$. This is followed by the analyses, which are presented in $\S 4 . \quad \S 5$ discusses our results and the managerial implications, and the final section contains some concluding 
remarks and provides directions for future research. All proofs to the propositions are contained in the appendix.

\section{MODEL}

Consider a market, or a specific segment as defined by its demand function (Dickson and Ginter, 1987; Mahajan and Jain, 1978), with two service firms - for example two hotels, in competition. In deciding whether to sell in advance, the firms have to decide on the price and capacity to allocate for advanced sale. Since this study is an attempt to structure a conceptual model of advanced sale, we define advanced sale to include all forms of advance bookings that are binding and that all such sale is consumed (see Dana 1999), and there are no other abstractions such as cancellations or no-shows. We also assume that there are no price changes after the reservations are confirmed.

We structure our model following that of Kreps and Scheinkman's (1983), in that firms in our model choose capacity allocations in a Cournot-type game played over two periods. In period 1 , the firms decide simultaneously on the capacity allocation for advanced sale. This is followed by period 2 , in which they decide simultaneously on the capacity allocation for sale at the time of consumption. Hence, in contrast to Kreps and Scheinkman's (1983) model, in which the firms choose capacities followed by prices, firms in our model choose capacities in both periods.

Let $\mathrm{t} \in\left\{\mathrm{t}_{\mathrm{A}}, \mathrm{t}_{0}\right\}$ be the time to the consumption date, $\mathrm{t}_{0}$ (when $\mathrm{t}=0$ ) be the time of production/consumption, and $t_{A}\left(\right.$ such that $\left.t_{A}>t_{0}=0\right)$ be the time of advanced sale. At $t_{0}$, the service is produced and consumed, and any unused capacity that arises has no salvage value after $t_{0}$. We assume that $t_{A}$ and $t_{0}$ are exogenous. In practice, $t_{A}$ is industry specific 
and depends on consumers' willingness to purchase a service prior to the date of consumption. For example, in the hotel and airline industries, firms are known to sell their capacities more than a year in advance in some markets (Lee and $\mathrm{Ng}, 2000$ ), hence $t_{A}$ is more than a year in these industries. Whilst in the advertising industry, TV networks are known to sell their advertising spaces approximately 6 months in advance (Mandese, 1995), hence $t_{A}$ represents 6 months in advance in such industries. We also assume that any sales are only made at $t_{\mathrm{A}}$ and $\mathrm{t}_{0}$ and all advance sales are conducted at $\mathrm{t}_{\mathrm{A}}$ and all spot sales are at $\mathrm{t}_{0}$. Let $\mathrm{C}_{\mathrm{i}}$ be the fixed cost of operation for firm $\mathrm{i}$. We assume that the variable cost of capacity is sufficiently small to be ignored. This is because, in capacity-sensitive service firms in general, the fixed cost of operation of service firms is much higher than the variable cost of capacity. This is especially so in the airlines and hotel industries (Kimes, 1989; Desiraju and Shugan, 1999). Let $\mathrm{k}_{0 \mathrm{i}}$ and $\mathrm{P}_{0 \mathrm{i}}$ be the capacity and the price of a unit capacity, respectively, at the time of consumption $t_{0}$ for firm $i$, where $i=1,2$. Similarly, let $\mathrm{k}_{\mathrm{Ai}}$ and $\mathrm{P}_{\mathrm{Ai}}$ be the capacity and the price of a unit capacity, respectively, at the time of advanced sale $t_{\mathrm{A}}$ for firm i. Let $\pi_{\mathrm{i}}$ be the payoffs of firm i. A firm $i$ chooses capacities $\mathrm{k}_{\mathrm{i}}=\left\{\mathrm{k}_{\mathrm{Ai}}, \mathrm{k}_{0 \mathrm{i}}\right\}$ to maximise profits. Assuming there is no discount factor, the firm's objective function can thus be defined as,

$$
\operatorname{Max}_{\cdot k} \pi_{\mathrm{i}}=\operatorname{Max} . \mathrm{k}\left[\left(\mathrm{P}_{\mathrm{Ai}} \mathrm{k}_{\mathrm{Ai}}+\mathrm{P}_{0 \mathrm{i}} \mathrm{k}_{0 \mathrm{i}}\right)-\mathrm{C}_{\mathrm{i}}\right]
$$

We assume that price is a linear decreasing function of total capacity available at any point of time $t$, as follows. 


$$
\begin{aligned}
& \mathrm{P}_{\mathrm{Ai}}=\alpha-\beta_{\mathrm{i}}\left(\mathrm{k}_{\mathrm{A} 1}+\mathrm{k}_{\mathrm{A} 2}+\mathrm{k}_{01}+\mathrm{k}_{02}\right) \\
& \mathrm{P}_{0 \mathrm{i}}=\alpha-\beta_{\mathrm{i}}\left(\mathrm{k}_{01}+\mathrm{k}_{02}\right)
\end{aligned}
$$

We will first examine the case when the firms are identical. In this case, the firms' response functions are similar, and hence the price sensitivities $\left(\beta_{\mathrm{i}}\right)$ are symmetric across the firms, $\beta_{\mathrm{i}}=\beta_{\mathrm{j}}=\beta, \mathrm{i} \neq \mathrm{j}, \mathrm{i}, \mathrm{j} \in\{1,2\}$. Following which, we examine the case when the firms are differentiated, with differing response functions such that the price sensitivities across the firms are asymmetric, $\beta_{\mathrm{i}} \neq \beta_{\mathrm{j}}$.

The use of a linear demand function is consistent with earlier game theoretic studies (e.g. Ingene and Parry, 1995; Jeuland and Shugan, 1983). Such functions have also been extensively used in empirical studies (see Lilien, Kotler and Moorthy, 1992). The linear demand function can be a reasonable approximation of a non-linear one, given that the latter can be defined as one that comprises a series of linear functions $\left(f(\mathrm{x})=\sum_{\mathrm{i}}\right.$ $f_{i}(\mathrm{x}): \mathrm{x}_{\mathrm{j}} \leq \mathrm{x} \leq \mathrm{x}_{\mathrm{k}}, \mathrm{i}=1$ to $\left.\mathrm{n}, \mathrm{j} \neq \mathrm{k}\right)$ over an appropriately partitioned $\left(\mathrm{x}_{\mathrm{j}} \leq \mathrm{x} \leq \mathrm{x}_{\mathrm{k}}\right)$ non-linear one, such that the range of each partition approaches zero $\left(\mathrm{ie} .\left(\mathrm{x}_{\mathrm{k}}-\mathrm{x}_{\mathrm{j}}\right) \rightarrow 0\right)$. The accuracy of a linear function as an approximation of a non-linear one thus depends on how the non-linear function is partitioned and the range of interest.

\section{ANALYSIS}

We first consider the case of a monopoly to provide a benchmark for comparisons later. This is followed by the case of duopolistic competition. Finally, we extend the analysis to examine the impact of asymmetric price sensitivities on pricing and capacity allocations for advanced sale, and for sale at the time of consumption. 
(a) Symmetric Price Sensitivity, $\left(\beta_{\mathrm{i}}=\beta_{\mathrm{j}}=\beta\right)$

For the case of a monopoly, the firm's response functions at time $\mathrm{t}_{\mathrm{A}}$ and $\mathrm{t}_{0}$, and its objective function, are as follows.

$$
\begin{aligned}
& \mathrm{P}_{\mathrm{A}}=\alpha-\beta\left(\mathrm{k}_{\mathrm{A}}+\mathrm{k}_{0}\right) \\
& \mathrm{P}_{0}=\alpha-\beta\left(\mathrm{k}_{0}\right) \\
& \operatorname{Max} \cdot \mathrm{k} \pi=\operatorname{Max} \cdot \mathrm{k}_{[}\left[\left(\mathrm{P}_{\mathrm{A}} \mathrm{k}_{\mathrm{A}}+\mathrm{P}_{0} \mathrm{k}_{0}\right)-\mathrm{C}\right]
\end{aligned}
$$

As with our previous study (Lee and $\mathrm{Ng}, 2000$ ), we focus only on the case when an interior solution exists. This is important in order to determine the extent of demand for a service when there are no constraints (Orkin, 1998). Hence, we assume that the optimal capacity allocation $\mathrm{k}^{*}=\left(\mathrm{k}_{0}{ }^{*}+\mathrm{k}_{\mathrm{A}}{ }^{*}\right)$ is within the limit of the firm's total capacity $\mathrm{K}$, i.e. $\mathrm{k}^{*} \leq \mathrm{K}$. Otherwise, the results will be driven by boundary conditions. This also implies that the firm would not be pricing down to fill remaining capacity since the marginal revenue in doing so would be negative. Solving the firm's payoff function, Lemma 1 follows, which describes the monopolist's optimal strategy in advanced sale.

Lemma 1: The monopolist's optimal strategy in advanced sale is such that $k_{0}{ }^{*}=$ $\alpha /(3 \beta),{k_{A}}^{*}=\alpha /(3 \beta), P_{0}{ }^{*}=(2 \alpha) / 3, P_{A}{ }^{*}=\alpha / 3$, and $\pi^{*}=\left[\left(\alpha^{2} /(3 \beta)\right)-C\right]$. 
Lemma 1 implies that a monopolist will allocate its capacity symmetrically over sale in advance and sale at the time of consumption, $\left(\mathrm{k}_{0}{ }^{*}=\mathrm{k}_{\mathrm{A}}{ }^{*}=\alpha / 3 \beta\right)$, and discount its prices for advanced sale such that $\mathrm{P}_{\mathrm{A}}{ }^{*}=\alpha / 3<\mathrm{P}_{0}{ }^{*}=2 \alpha / 3$.

In the case of duopolistic competition, when $\beta_{\mathrm{i}}=\beta_{\mathrm{j}}=\beta$, the firms' response functions are as follows.

$$
\begin{aligned}
& \mathrm{P}_{\mathrm{Ai}}=\mathrm{P}_{\mathrm{A}}=\alpha-\beta\left(\mathrm{k}_{\mathrm{A} 1}+\mathrm{k}_{\mathrm{A} 2}+\mathrm{k}_{01}+\mathrm{k}_{02}\right) \\
& \mathrm{P}_{0 \mathrm{i}}=\mathrm{P}_{0}=\alpha-\beta\left(\mathrm{k}_{01}+\mathrm{k}_{02}\right)
\end{aligned}
$$

In accordance to the criteria of the sub game perfection (e.g. Rasmusen, 1994), we shall first derive the firms' optimal capacity allocations for advanced sale, given the firms' capacity allocation at the time of consumption (i.e. $\mathrm{k}_{\mathrm{Ai}} * \mid \mathrm{k}_{0}$ ). Lemma 2 follows, which describes the solution $\mathrm{k}_{\mathrm{Ai}} * \mid \mathrm{k}_{0}$.

Lemma $2: k_{A i} * \mid k_{0}=\left[\alpha-\beta\left(k_{01}+k_{02}\right)\right] /(3 \beta)$, where $k_{0}=\left\{k_{01}, k_{02}\right\}$.

Given the solution $\mathrm{k}_{\mathrm{Ai}} * \mid \mathrm{k}_{0}$, we proceed to solve for the firms' optimal capacity allocations at the time of consumption, following which we can derive the Nash (1950) equilibrium in capacity allocations for sale in advance and at the time of consumption.

Lemma 3: The Nash equilibrium is such that for sale at $t_{0}: k_{01} *=k_{02} *=\alpha /(3 \beta)$, and $P_{01} *=P_{02} *=\alpha / 3$, and for sale at $t_{A}: k_{A 1} *=k_{A 2} *=\alpha /(9 \beta)$, and $P_{A 1} *=P_{A 2} *$ $=\alpha / 9$. The firms' equilibrium payoffs are $\pi_{1}{ }^{*}=\pi_{2}{ }^{*}=\left[\alpha^{2}(10 / 81)-C\right]$. 
From Lemma 1 and 3, it is immediately obvious that the total capacities allocated for sale at time of consumption is higher under duopolistic competition $\left(\mathrm{k}_{01}{ }^{*}+\mathrm{k}_{02}{ }^{*}=\right.$ $2 \alpha / 3 \beta)$, compared to that under a monopoly $\left(\mathrm{k}_{0}{ }^{*}=\alpha / 3 \beta\right)$.

Proposition 1: $\left(k_{01}{ }^{*}+{k_{02}}{ }^{*}\right)=2 \alpha / 3 \beta$, under duopolistic competition, compared to $k_{0}{ }^{*}=\alpha / 3 \beta$, under a monopoly.

However, the total capacities allocated for advanced sale is lower under duopolistic competition $\left(\mathrm{k}_{\mathrm{A} 1}{ }^{*}+\mathrm{k}_{\mathrm{A} 2}{ }^{*}=2 \alpha / 9 \beta\right)$, compared to that under a monopoly $\left(\mathrm{k}_{\mathrm{A}}{ }^{*}=\right.$ $\alpha / 3 \beta)$.

Proposition 2: $\left(k_{A 1}{ }^{*}+k_{A 2}{ }^{*}\right)=2 \alpha / 9 \beta$, under duopolistic competition, compared to $k_{A}{ }^{*}=\alpha / 3 \beta$, under a monopoly.

This is rather surprising, as intuitively, we would expect that the firms would increase their capacity allocations for advanced sale under competitive pressure (See McKenna, 1989), to sell capacity earlier than their rivals. However, advanced sale fetches a price lower than that under sale at the time of consumption, $\mathrm{P}_{\mathrm{A} 1} *=\mathrm{P}_{\mathrm{A} 2} *=\alpha / 9<$ $\mathrm{P}_{01} *=\mathrm{P}_{02} *=\alpha / 3$ (Lemma 3 ). Hence, while competitive pressure would motivate the firms to sell in advance in order to avoid the risk of lost sales, the reduced profit margins 
causes them to decrease capacity allocations for advanced sale. Furthermore, the higher profit margins at the time of consumption would also induce the firms to increase capacity allocations for sale at that time (Quain, Sansbury and Quinn, 1999). However, the market price sensitivity to the total capacity allocations at the time of consumption prevents the firms from allocating excessive capacities for sale at that time. The overall effect of the interactions of these forces is therefore a reduction in the proportion of a firm's total capacity allocated for advanced sale under duopolistic competition $\left(\mathrm{k}_{\mathrm{Ai}}{ }^{*} /\left(\mathrm{k}_{0 \mathrm{i}}{ }^{*}\right.\right.$ $\left.\left.+\mathrm{k}_{\mathrm{Ai}}{ }^{*}\right)=1 / 4\right)$, compared to that under a monopoly $\left(\mathrm{k}_{\mathrm{A}}{ }^{*} /\left(\mathrm{k}_{0}{ }^{*}+\mathrm{k}_{\mathrm{A}}{ }^{*}\right)=1 / 2\right)$.

Proposition 3: ${k_{A i}}^{*} /\left(k_{0 i}{ }^{*}+k_{A i}{ }^{*}\right)=1 / 4$, under duopolistic competition, compared to ${k_{A}}^{*} /\left(k_{0}{ }^{*}+{k_{A}}^{*}\right)=1 / 2$, under a monopoly.

\section{(b) Asymmetric Price Sensitivity, $\left(\beta_{\mathrm{i}} \neq \beta_{\mathrm{j}}\right)$}

We shall now investigate how asymmetric price sensitivities impact the firms' decisions on advanced sale. In this case, $\beta_{\mathrm{i}} \neq \beta_{\mathrm{j}}, \mathrm{i}, \mathrm{j} \in\{1,2\}$, which implies that $\mathrm{P}_{\mathrm{Ai}} \neq \mathrm{P}_{\mathrm{Aj}}$, and $\mathrm{P}_{0 \mathrm{i}} \neq \mathrm{P}_{0 \mathrm{j}}$. Let $\beta_{1}=\beta_{\mathrm{H}}$ and $\beta_{2}=\beta_{\mathrm{L}}$, such that $\beta_{\mathrm{L}}<\beta_{\mathrm{H}}$, without loss of generality. The inequality $\beta_{1}=\beta_{\mathrm{H}}>\beta_{2}=\beta_{\mathrm{L}}$ implies that the market is more price sensitive to capacity allocations by firm 1 than by firm 2, which reflects that firms 1 and 2 are differentiated. Lemma 4 presents the Nash equilibrium for this case.

Lemma 4: The Nash equilibrium is such that:

- for sale at $t_{0}:{k_{0 H}}^{*}=\left(2 \alpha \beta_{L}-\alpha \beta_{H}\right) /\left(3 \beta_{H} \beta_{L}\right), k_{0 L}{ }^{*}=\left(2 \alpha \beta_{H}-\alpha \beta_{L}\right) /\left(3 \beta_{H} \beta_{L}\right)$, and $P_{0 H}{ }^{*}=\left(2 \alpha \beta_{L}-\alpha \beta_{H}\right) /\left(3 \beta_{L}\right), P_{0 L}{ }^{*}=\left(2 \alpha \beta_{H}-\alpha \beta_{L}\right) /\left(3 \beta_{H}\right)$ 
- for sale at $t_{A}: k_{A H}{ }^{*}=\left(5 \alpha \beta_{L}-4 \alpha \beta_{H}\right) /\left(9 \beta_{H} \beta_{L}\right), k_{A L}{ }^{*}=\left(5 \alpha \beta_{H}-4 \alpha \beta_{L}\right) /\left(9 \beta_{H} \beta_{L}\right)$, and $P_{A H}{ }^{*}=\left(5 \alpha \beta_{L}-4 \alpha \beta_{H}\right) /\left(9 \beta_{L}\right), P_{A L}{ }^{*}=\left(5 \alpha \beta_{H}-4 \alpha \beta_{L}\right) /\left(9 \beta_{H}\right)$

The equilibrium payoffs are $\pi_{H}{ }^{*}=\left[\left(61 \alpha^{2}{\beta_{L}}^{2}-76 \alpha^{2} \beta_{H} \beta_{L}+25 \alpha^{2} \beta_{H}^{2}\right) /\left(81 \beta_{H} \beta_{L}^{2}\right)-\right.$ C] and $\pi_{L}^{*}=\left[\left(61 \alpha^{2} \beta_{H}^{2}-76 \alpha^{2} \beta_{H} \beta_{L}+25 \alpha^{2} \beta_{L}^{2}\right) /\left(81 \beta_{H}^{2} \beta_{L}\right)-C\right]$.

When price sensitivities are asymmetric, $\beta_{\mathrm{i}} \neq \beta_{\mathrm{j}}$, optimal pricing and capacity allocations differ across the firms.

$$
\begin{aligned}
& \text { Proposition 4: } P_{A H}{ }^{*}<P_{A L}{ }^{*}, P_{O H}{ }^{*}<P_{O L}{ }^{*} \text {, and }\left(P_{O H}{ }^{*}-P_{A H}{ }^{*}\right)=\left(P_{O L}{ }^{*}-P_{A L}{ }^{*}\right)=\left[\left(\alpha \beta_{L}\right.\right. \\
& \left.\left.\left.+\alpha \beta_{H}\right)\right] /\left(9 \beta_{L}\right)\right] \text {. }
\end{aligned}
$$

As expected, a firm charges a lower price for both advanced sale and sale at the time of consumption, if its response function is more price sensitive, $\mathrm{P}_{\mathrm{AH}}{ }^{*}<\mathrm{P}_{\mathrm{AL}}{ }^{*}$, and $\mathrm{P}_{0 \mathrm{H}}{ }^{*}<\mathrm{P}_{0 \mathrm{~L}}{ }^{*}$. In addition, as the market is price sensitive to the combined capacities of both the firms, rather than to just the capacity allocations of any one firm, the price reduction for advanced sale is similar across both the firms, $\left(\mathrm{P}_{0 \mathrm{H}}{ }^{*}-\mathrm{P}_{\mathrm{AH}}{ }^{*}\right)=\left(\mathrm{P}_{0 \mathrm{~L}}{ }^{*}-\mathrm{P}_{\mathrm{AL}}{ }^{*}\right)$.

$$
\text { Proposition 5: }{k_{A H}}^{*}<{k_{A L}}^{*}, k_{O H}{ }^{*}<{k_{0 L}}^{*} \text {, and } \partial\left(k_{A i}{ }^{*} / k_{0 i}{ }^{*}\right) / \partial \beta_{i}<0 \text {. }
$$

Although the optimal price for the firm with higher price sensitivity is lower, and therefore we expect the capacity allocation to be higher, the derivation shows that the firm should allocate less capacity for both advanced sale and sale at the time of 
consumption, if its response function is more price sensitive. Indeed, the ratio of a firm's capacity allocation for advanced sale to its allocation for sale at the time of consumption $\left(\mathrm{k}_{\mathrm{Ai}}{ }^{*} / \mathrm{k}_{0 \mathrm{i}}\right)$, decreases with increased price sensitivity of the market to its capacity supplies $\left(\partial\left(\mathrm{k}_{\mathrm{Ai}}{ }^{*} / \mathrm{k}_{0 \mathrm{i}}{ }^{*}\right) / \partial \beta_{\mathrm{i}}<0\right)$. Although counter intuitive, this can be explained as follows. The firms' prices are reduced as their capacity allocations for sale increases. However, for a firm whose response function is more price sensitive, an increase in capacity allocations in both times of sale reduces its prices more than those of a firm whose response function is less price sensitive. Hence, a firm whose response function is more price sensitive, would reduce its capacity allocations and allocate less capacity for both times of sale than one whose response function is less price sensitive.

In addition, a firm whose response function is more price sensitive commands lower prices for both times of sale, but sale at the time of consumption carries a price premium over that in advance. Such a firm would therefore reduce its capacity allocation for advanced sale, preferring to sell more at the time of consumption, in order to benefit from the higher prices obtainable at that time. It follows that the ratio of a firm's capacity allocation for advanced sale to its allocation for sale at the time of consumption decreases with an increase in price sensitivity. Indeed, as a firm's response function becomes increasingly price sensitive, in the limit when $\beta_{\mathrm{H}} \rightarrow 5 \beta_{\mathrm{L}} / 4$, the firm's capacity allocation for advanced sale approaches zero, $\mathrm{k}_{\mathrm{AH}}{ }^{*} \rightarrow 0$.

Proposition 6: $k_{A H}{ }^{*} \rightarrow 0$, as $\beta_{H} \rightarrow 5 \beta_{L} / 4$. 
This proposition implies that under conditions of extreme price sensitivities, it can be sub-optimal for a service firm to sell any capacity in advance.

\section{DISCUSSION AND MANAGERIAL IMPLICATIONS}

The surge of affordable information technology and its advancement over the last decade have accelerated the development of computational algorithms for revenue management programme. This has resulted in an increased adoption of revenue management programmes by many other services sectors such as restaurants (Kimes, 1999), rail, (Anonymous, 1999), car rental (Geraghty and Johnson, 1997), air cargo (Kasilingam, 1997), bulk power (Anonymous, 1997), and electricity (Ashworth, 1997). However, our analysis raises several concerns about the use of such programmes, which service firms should be aware of.

Through our simple stylised model we show that the total capacity allocated for advanced sale is lower under duopolistic competition, compared to that under a

monopoly (Proposition 2). Individually, each competing firm reduces the proportion of its total capacity allocated for advanced sale (Proposition 3). These suggest that the use of revenue management systems could potentially lead to sub-optimal capacity allocations by firms in competition such that excessive capacity is being offered for sale in advance. This is because revenue management systems in general "treat quantity demanded as a random variable drawn from distributions whose parameters are estimated from historical figures and conditioned on the firm's (and competitor's) product price and availability decisions" (Williams, 1999, p. 40). This implies that decisions that are based 
on revenue management systems implicitly ignore competitive interactions and consider only monopolistic situations. From Propositions 2 and 3, Corollary 1 thus follows.

Corollary 1: Decisions based on YMS, which fail to take into explicit account of competitive interactions, are sub-optimal in that excessive capacity is allocated for advanced sale.

Our study also implies that a firm's advanced sale strategy in terms of capacity allocations depends on how sensitive its prices are to the total capacity available in the market (Proposition 5). In this regard, a service firm whose prices are less (more) sensitive to the total market capacity should increase (decrease) its capacity allocated for advanced sale.

Corollary 2: A service firm whose prices are less (more) sensitive to the total market capacity should increase (decrease) its capacity allocated for advanced sale.

Indeed, our analysis shows that, for firms whose prices are highly sensitive to the total market capacity, such firms should avoid advanced sale altogether (Proposition 6).

Corollary 3: Advanced sale is suitable for service firms whose prices are less sensitive to the total market capacity, but not for those whose prices are very sensitive to the total market capacity. 
Corollary 3 also implies that it is important that revenue management systems take into account, not only competitive interactions, but also the relative price sensitivities, to the total market supply, of the firms in competition. Failure to do so could lead to sub-optimal decisions in capacity allocations for advanced sale. This is in direct contrast to Belobaba's (1989) assertion that “....although pricing has a direct impact on revenues, an airline can seldom impose price changes without taking the reactions of its competitors into account. Seat inventory control, on the other hand, is a tactical component of revenue management that is entirely under the control of each individual" (p. 183). This suggests (incorrectly) that capacity allocations can be made monopolistically.

Corollary 4: Failure by revenue management systems to take into account both competitive interactions and the relative price sensitivities of the competing firms could lead to sub-optimal decisions in capacity allocations for advanced sale.

In some industries, service firms, which are aware that the market is price sensitive to capacity availability, have attempted to conceal the actual capacity available so as to be able to command better prices. For example, in the airline industry, most of the firms' capacities (seats) are sold through travel agents using a computer reservation system (CRS). In using the CRS, the total number of seats available is not shown when capacity availability is high. However, if only a limited number of seats are still 
available, then the exact number is reported by the CRS. Such a "cloaking" strategy can be effective for service firms whose prices are highly sensitive to capacity availability.

\section{CONCLUSION}

The phenomenon of advanced sale in services marketing has been largely overlooked by the academic community in marketing. With the advent of the new economy, dominated by services and highly competitive in nature, it is our contention that this area of research should not be ignored. In this paper, we set out to investigate the phenomenon and the impact of competition on this practice. We have done this in the context of a Cournot duopoly model over two stages of time. Where previous studies of this nature assumed some demand profile in advance, our study explicitly models the market price sensitivity to capacity and the effects of competition, highlighting the marketing issues relevant to advanced sale.

In our view, our paper answers a few questions. Is advanced selling optimal? We discover that it is, even when no uncertainty is present. Is it optimal when there is competition? The answer we find is also largely yes, but depending on the level of price sensitivity relative to the competitor, and even where there is advanced sale, there should be a reduction in capacity from what is allocated under a monopoly context. However, this paper raises more questions than it answers definitively. What would happen when uncertainty is introduced? Since we have examined the impact of price sensitivity and competition on the advanced sale strategies of competing firms, a natural extension of this study is to investigate how demand uncertainty affects advanced sale. How would the impact of competition be if the firms can choose the time of selling in advance? In 
our model, competing firms choose capacity allocations for advanced sale and for sale at the time of consumption. We assumed that the time for advanced sale is exogenous, and that prices are endogenous to the firms' capacity allocations. However, effective pricing and timing decisions, in addition to the proper allocation of capacities for sale over time, are also important in improving revenue from yield management. Future research effort should therefore be devoted to investigating the optimal timing of advanced sale for competing firms, as well as how price (instead of capacity) setting would impact on the practice.

Method-wise, we adopted a game theoretic approach to examine the optimality of advanced sale for competing firms. The use of game theory, which is referred to as interactive decision theory (Aumann, 1989), provides us with a systematic way of analyzing problems that involve strategic interactions between competing firms. We hope our paper will provide greater stimulus to researchers in service marketing to perform theoretical research based on deductive science, to further increase the rigour of research in service marketing.

\section{REFERENCES}

Alstrup, J., Boas, S., Madsen, O. and Vidal, R. (1986) 'Booking policy for flights with two types of passengers', European Journal of Operations Research, Vol. 27, pp.274-288.

Anjos, M.F., Cheng, R.C. H. and Currie, C. S. M. (2005) 'Optimal pricing policies for perishable products,' European Journal of Operational Research, Vol 166/1, pp.246-254.

Anonymous (1994) 'Chunnel ticket sales off to a slow start', ENR, Jan 24, Vol. 19.

Ashworth, M. (1997) 'Revenue management', Electric Perspectives, Vol. 22, pp.36-44. 
Aumann, R.J. (1989) 'Game theory', In J. Eatwell, M. Milgate and P. Newman (Eds.), The New Palgrave Game Theory. UK: The Macmillan Press.

Badinelli, R.D. and Olsen, M.D. (1990) 'Hotel yield management using optimal decision rules', Journal of International Academy of Hospitality Research, (Nov 26, issue.1),

Electronic Journal URL: http://scholar.lib.vt.edu/ejournals/JIAHR/issue1.html

--- (1995) Managing Services Marketing. Orlando, FL: The Dryden Press.

Belobaba, P.P. (1989) 'Application of a probabilistic decision model to airline seat inventory control', Operations Research, Vol. 37, pp.183-197.

Berry, L., Zeithaml, V. and Parasuraman, A. (1984) 'Responding to demand fluctuations: key challenge for service businesses', Educators' Conference Proceedings, Chicago: American Marketing Association.

Bertrand, J. (1838), 'Review of Cournot', Journal des Savants, pp.499-508.

Bertsimas, D. and de Boer, S. (2005) 'Simulation-based booking limits for airline revenue management' Operations Management, Vol. 53/1, pp. 90-106.

Bitrand, G. and Caldentey, R. (2003) 'An Overview of Pricing Models for Revenue Management', Manufacturing \& Service Operations Management, Vol.5/3, pp.203-229.

Biyalogorsky, E. and Gerstner, E. (2004) 'Contingent pricing to reduce price risks', Marketing Science, Vol.23/1, pp.146-155.

Bodily, S.E and Weatherford, L.R. (1995) 'Perishable-asset revenue management: generic and multiple-price yield management with diversion', Omega, International Journal of Management Science, Vol. 23, pp.173-185.

Boyd, E.A. and Bilegan, I.C. (2003) 'Revenue Management and E-Commerce' Management Science, Vol. 49/10, pp.1363-1386.

Bruhn, M. and Georgi, D. (2006) Services Marketing: Managing the Service Value Chain. Harlow: Prentice Hall FT.

Brumelle, S. and Walczak, D. (2003) 'Dynamic airline revenue management with multiple semi-Markov demand', Operations Research, Vol. 51/1, pp.137-148.

Chase Jr., C.W. (1999) "Revenue management: A review', Journal of Business Forecasting Methods and Systems, Vol. 18, pp.2 \& 28. 
Chiang, W.C., Chen, J.C.H. and Xu, X. (2007) 'An overview of research on revenue management: current issues and future,' International Journal of Revenue Management, Vol. 1/1, pp.97-128.

Cournot, A.A. (1838) Recherches sur les principes mathématiques de la theorie des richesses. Paris: 1838. English Translation: (N. Bacon, trans.1897), Researches into the mathematical principles of the theory of wealth. New York: Macmillan \& Company.

Dana Jr., J.D. (1998), 'Advance-purchase discounts and price discrimination in competitive markets', Journal of Political Economy, Vol. 106/2, pp.395-422.

Dana Jr., J.D. (1999), 'Using yield management to shift demand when the peak time is unknown', Rand Journal of Economics, Vol. 30, pp.456-474.

Desiraju, R. and Shugan, S.M. (1999) 'Strategic service pricing and yield management', Journal of Marketing, Vol. 63, pp.44-56.

Dickson, P.R. and Ginter, J.L (1987) 'Market segmentation, product differentiation, and marketing strategy', Journal of Marketing, Vol. 51, pp.1-10.

Edgett, S. and Parkinson, S. (1993) 'Marketing for service industries - a review', The Service Industries Journal, Vol. 13, p.19.

Geraghty, M.K. and Johnson, E. (1997) 'Revenue management saves National Car Rental', Interfaces, Vol. 27, pp.107-127.

Glover, F., Glover, R., Lorenzo, J. and McMillan, C. (1982) 'The passenger mix problem in the scheduled airlines', Interfaces, Vol. 12, pp.73-79.

Harris, F.H. and Peacock, P. (1995) 'Hold my place, please', Marketing Management, Vol. 4, pp.34-46.

Hersh, M. and Ladany, S.P. (1978) 'Optimal seat allocation for flights with one intermediate stop', Computers and Operations Research, Vol. 5, pp.31-37.

Ingene, C.A. and Parry, M.E. (1995) 'Channel coordination when retailers compete', Marketing Science, Vol. 14, pp.360-377.

Ingold, A., Yeoman, I. and McMohan, U. (2001) 'Yield Management: Strategies for the Service Industries. London: Continuum.

Iyer, A.V., Deshpande, V. and Wu, Z. (2003) 'A postponement model for demand management’, Management Science, Vol. 49/8, pp.983-1002.

Jeuland, A.P. and Shugan, S.M (1983) 'Managing channel profits', Marketing Science, Vol. 2, pp.239-272. 
Johnson, E. (1970) 'The selling of services', In V. Buell (Ed.), Handbook of Modern Marketing. New York: McGraw-Hill.

Kasper, H., van Helsdingen, P. and Gabbott M. (2006) Services Marketing Management: A Strategic Perspective. Hoboken, New Jersey: John Wiley \& Sons Ltd. $2^{\text {nd }}$ Edition.

Kasilingam, R.G. (1997) 'Air cargo revenue management: characteristics and complexities’, European Journal Of Operational Research, Vol. 96, pp.36-44.

Kimes, S.E. (1989) 'Yield management: a tool for capacity-constrained service firms', Journal of Operations Management, Vol. 8, pp.348-363.

---- (1999) 'Implementing restaurant revenue management', Cornell Hotel and Restaurant Administration Quarterly, Vol. 40, pp.16-21.

---- (2000) 'A strategic approach to yield management,' In A.Ingold, I. Yeoman and U. McMohan-Beattie, 'Yield Management: Strategies for the Service Industries, pp.3-14. London: Continuum.

---- (2003) 'Revenue management: A retrospective look', Cornell Hotel and Restaurant Administration Quarterly, Vol. 44/5 \& 6, pp. 131-138.

Kreps, D.M. and Scheinkman, J.A. (1983) 'Quantity precommitment and Bertrand competition yield Cournot outcomes', Bell Journal of Economics, Vol. 14, pp.326-337.

Ladany, S.P. (1976) 'Dynamic operating rules for motel reservations', Decision Sciences, Vol. 7, pp.829-240.

Lee, K. S. and Ng, I.C. L. (2001), 'advanced sale of service capacities: Impact of price sensitivity to supply on optimal pricing and capacity allocations", Journal of Business Research, Vol. 54, pp.219-225.

Lieberman, V. and Yechiali, U. (1978) 'On the hotel overbooking problem: An inventory problem with stochastic cancellations’, Management Science, Vol. 24, pp.11171126.

Lieberman, W.H. (1993) 'Debunking the myths of yield management', Cornell Hotel and Restaurant Administration Quarterly, Vol. 34, pp.34-41.

Lilien, G.L., Kotler, P., and Moorthy, S. (1992) Marketing Models. Englewood Cliffs, N.J: Prentice-Hall. 
Littlewood, K. (1972) 'Forecasting and control of passenger bookings', AGIFORS Symposium Proceedings, pp.95-117.

Lloyds Aviation Economist (1985) 'Yield managers now control tactical marketing', Lloyds Aviation Economist, May, pp.12-13.

Mahajan, V.and Jain, A.K. (1978) 'An approach to normative segmentation', Journal of Marketing Research, Vol. 15, pp.338-345.

Management Accounting (1999) 'Rail companies warned against 'one size fits all' solutions', Management Accounting, Vol. 77, p.5.

Mandese, J. (1995) 'The buying and selling', Advertising Age, Vol. 66, p.20.

McKenna, J.T. (1989) 'TWA leads U.S. carriers in cutting domestic fares', Aviation Week \& Space Technology, New York, Vol. 131, p.92.

Montgomery, S.L. (1988) Profitable Pricing Strategies. New York: McGraw-Hill .

Nagle, T.T. and Holden, R.K. (1995) The Strategy and Tactics of Pricing. Englewood Cliffs, N.J.: Prentice-Hall.

Nash, John (1950) 'Equilibrium points in n-person games', Proceedings of the National Academy of Sciences, Vol. 36, pp.48-49.

Ng, I.C.L, Wirtz, J. and Lee, K.S. (1999) 'The strategic role of unused service capacity', International Journal of Service Industry Management, Vol.10, pp.211-238.

$\mathrm{Ng}$, I.C.L (2007) 'Advanced demand and a critical analysis of revenue management', Service Industries Journal, Vol.27/5, forthcoming.

Orkin, E.B. (1988) 'Boosting your bottom line with yield management', Cornell Hotel and Restaurant Administration Quarterly, Vol. 28, pp.52-56.

---- (1998) 'Wishful thinking and rocket science', Cornell Hotel and Restaurant Administration Quarterly, Vol. 39/4, pp.15-19.

Pfeifer, P.E. (1989) 'The airline discount fare allocation problem', Decision Sciences, Vol. 20, pp.149-157.

Png, I.P.L. (1991) 'Most-favored-customer protection versus price discrimination over time', Journal of Political Economy, Vol. 99, pp.1010-1028.

---- (1989) 'Reservations: customer insurance in the marketing of capacity', Marketing Science, Vol. 8, pp.248-264. 
Pridmore, J. (1987) ‘Another niche, another show', Venture, Jan, pp.38-44.

Quain, W.J., Sansbury, M. and Quinn, D. (1999) 'Revenue enhancement, part 3', Cornell Hotel and Restaurant Administration Quarterly, Vol. 40, pp.76-83.

Radas, S. (1998) 'Managing service demand: shifting and bundling', Journal of Service Research, Vol. 1, pp.47-64.

Raman, A., DeHoratius, N. and Ton, Z. (2001) 'Execution: The missing link in retail operations', California Management Review, Vol. 43/2, pp.136-152.

Rasmusen, E. (1994) Games and Information: An Introduction to Game Theory. Cambridge, MA: B.Blackwell, $2^{\text {nd }}$ edition.

Rathmell, J. (1966) 'What is meant by services?', Journal of Marketing, Vol. 30, pp.3236.

Regan, W. (1963) 'The service revolution,' Journal of Marketing, Vol. .27, pp.57-62.

Relihan III, W.J. (1989) 'The yield management approach to hotel-room pricing', Cornell Hotel and Restaurant Administration Quarterly, Vol. 30, pp.40-45.

Rothstein, M. (1971) “An airline overbooking model', Transportation Science, Vol. 5, pp.180-192.

---- (1974) 'Hotel overbooking as a Markovian sequential decision process', Decision Sciences, Vol. 5, pp.389-394.

---- (1985) 'Operations research and the airline overbooking problem', Operations Research, Vol. 33, pp.237-248.

Sasser, W. E. (1976) 'Match supply and demand in service industries', Harvard Business Review, Vol. 54, pp.133-40.

Shemwel,1 D.J. and Cronin, J.C. (1994) 'Services marketing strategies for coping with demand/supply imbalances’, Journal of Services Marketing, Vol. 8/4, pp.14-24.

Shugan, S.M. and Xie, J. (2000) 'Advance pricing of services and other implications of separating purchase and consumption', Journal of Service Research, Vol. 2, pp.227-239.

Shugan, S.M. and Xie, J. (2004) 'Advance selling for services', California Management Review, Vol.46/3, pp.37-54.

Shugan, S.M. and Xie, J. (2005) 'Advance selling as a competitive tool', International Journal of Research in Marketing, Vol.22, pp.351-373. 
Talluri K.T., and van Ryzin G. (2004) 'Theory and Practice of Revenue Management (International Series in Operations Research \& Management Science). Netherlands: Springer Publishers.

Thompson, H.R. (1961) 'Statistical problems in airline reservation control', Operational Research Quarterly, Vol. 12, pp.167-185.

Toh, R. (1979) 'Airline revenue yield protection: Joint reservation control over full and discount fare sales', Transportation Journal, Vol. 19, pp.74-80.

---- (1985), 'An inventory depletion overbooking model for the hotel industry', Journal of Travel Research, (Spring), pp.24-30.

Walley, W. (1990) 'Upfront TV season: Ante up for the big poker game', Advertising Age, Vol. 33, p.42.

Weatherford, L.R. and Pfeifer, P.E. (1994) 'The economic value of using advance booking of orders', Omega, International Journal of Management Science, Vol. 22, pp.105-111.

Williams, L. (1999) 'Revenue management: microeconomics and business modeling', Business Economics, Vol. 34, pp.39-45.

Xie, J. and Shugan, S.M. (2001) 'Electronic tickets, smart cards and online prepayments: When and how to advance sell', Marketing Science, Vol. 20, pp.219-243.

Zeithaml, V.A, Bitner M.J. and Gremler D.D. (2003) Services Marketing: Integrating Customer Focus Across the Firm. Singapore: McGraw Hill. 


\section{APPENDIX}

\section{Proof of Lemma 1}

Substitute equation (4) and (5) for $\mathrm{P}_{\mathrm{A}}$ and $\mathrm{P}_{0}$ respectively, into the objective function (6), to obtain $\pi=\left[\left(\alpha-\beta\left(\mathrm{k}_{\mathrm{A}}+\mathrm{k}_{0}\right)\right) \mathrm{k}_{\mathrm{A}}+\left(\alpha-\beta\left(\mathrm{k}_{0}\right)\right) \mathrm{k}_{0}\right]-\mathrm{C}$. Hence, FOC wrt $\mathrm{k}_{\mathrm{A}}: 0=\alpha-2 \beta \mathrm{k}_{\mathrm{A}}-$ $\beta \mathrm{k}_{0}$, and FOC wrt $\mathrm{k}_{0}: 0=\alpha-2 \beta \mathrm{k}_{0}-\beta \mathrm{k}_{\mathrm{A}}$. Solving the FOCs: $\mathrm{k}_{0}{ }^{*}=\alpha / 3 \beta$ and $\mathrm{k}_{\mathrm{A}}{ }^{*}=\alpha / 3 \beta$. Substitute $\mathrm{k}_{0}{ }^{*}$ and $\mathrm{k}_{\mathrm{A}}{ }^{*}$ into equations (4) and (5): $\mathrm{P}_{0}{ }^{*}=2 \alpha / 3$, and $\mathrm{P}_{\mathrm{A}}{ }^{*}=\alpha / 3$. Hence, $\pi^{*}=$ $(\alpha / 3)(\alpha / 3 \beta)+(2 \alpha / 3)(\alpha / 3 \beta)-C=\left(\alpha^{2} / 3 \beta\right)-$ C. Q.E.D.

\section{Proof of Lemma 2}

$\pi_{\mathrm{i}}=\mathrm{P}_{\mathrm{Ai}} \mathrm{k}_{\mathrm{Ai}}+\mathrm{P}_{0 \mathrm{i}} \mathrm{k}_{0 \mathrm{i}} \mathrm{C} \Rightarrow \pi_{\mathrm{i}}=\left[\alpha-\beta\left(\mathrm{k}_{\mathrm{Ai}}+\mathrm{k}_{\mathrm{Aj}}+\mathrm{k}_{0 \mathrm{i}}+\mathrm{k}_{0 \mathrm{j}}\right)\right] \mathrm{k}_{\mathrm{Ai}}+\mathrm{P}_{0 \mathrm{i}} \mathrm{k}_{0 \mathrm{i}} \mathrm{C}$ for firm i. FOC wrt $\mathrm{k}_{\mathrm{Ai}} \mid \mathrm{k}_{0}$ : $\mathrm{k}_{\mathrm{Ai}}=\left(\alpha-\beta \mathrm{k}_{\mathrm{Aj}}-\beta \mathrm{k}_{0 \mathrm{i}}-\beta \mathrm{k}_{0 \mathrm{j}}\right) / 2 \beta \Rightarrow \mathrm{k}_{\mathrm{Ai}} * \mathrm{k}_{0}=\left(\alpha-\beta\left(\mathrm{k}_{0 \mathrm{i}}+\mathrm{k}_{0 \mathrm{j}}\right)\right] /(3 \beta)$. Q.E.D.

\section{Proof of Lemma 3}

At $\mathrm{t}_{0}, \pi_{0 \mathrm{i}}=\mathrm{P}_{0 \mathrm{i}} \mathrm{k}_{0 \mathrm{i}} \mathrm{C} \Rightarrow \pi_{0 \mathrm{i}}=\left[\alpha-\beta\left(\mathrm{k}_{0 \mathrm{i}}+\mathrm{k}_{0 \mathrm{j}}\right)\right] \mathrm{k}_{0 \mathrm{i}}$ for firm i. FOC wrt $\mathrm{k}_{0 \mathrm{i}}: \mathrm{k}_{0 \mathrm{i}}=\left(\alpha-\beta \mathrm{k}_{0 \mathrm{j}}\right) / 2 \beta \Rightarrow$ $\mathrm{k}_{01}{ }^{*}=\mathrm{k}_{02}{ }^{*}=\alpha / 3 \beta$. Substitute $\mathrm{k}_{01}{ }^{*}$ and $\mathrm{k}_{02}{ }^{*}$ into $(8) \Rightarrow \mathrm{P}_{01}{ }^{*}=\mathrm{P}_{02}{ }^{*}=\alpha / 3$. Substitute $\mathrm{k}_{01}{ }^{*}, \mathrm{k}_{02}{ }^{*}$, into $\mathrm{k}_{\mathrm{Ai}} \mid \mathrm{k}_{0}\left(\right.$ Lemma 2): $\mathrm{k}_{\mathrm{A} 1}{ }^{*}=\mathrm{k}_{\mathrm{A} 2}{ }^{*}=\alpha / 9 \beta$. Substitute $\mathrm{k}_{\mathrm{A} 1}{ }^{*}, \mathrm{k}_{\mathrm{A} 2}{ }^{*}$ into $(7) \Rightarrow \mathrm{P}_{\mathrm{A} 1}{ }^{*}=\mathrm{P}_{\mathrm{A} 2}{ }^{*}=$ $\alpha / 9$. Substituting $\mathrm{P}_{\mathrm{Ai}}{ }^{*}, \mathrm{k}_{\mathrm{Ai}}{ }^{*}, \mathrm{P}_{0 \mathrm{i}}{ }^{*}, \mathrm{k}_{0 \mathrm{i}}{ }^{*}$ into $\pi_{\mathrm{i}} \Rightarrow \pi_{1}{ }^{*}=\pi_{2}{ }^{*}=10 \alpha^{2} / 81$ - C. Q.E.D.

\section{Proof of Proposition 1}

From Lemma $3: \mathrm{k}_{01}{ }^{*}=\mathrm{k}_{02}{ }^{*}=\alpha / 3 \beta \Rightarrow \mathrm{k}_{01}{ }^{*}+\mathrm{k}_{02}{ }^{*}=2 \alpha / 3 \beta$ for a duopoly. From Lemma 1 , $\mathrm{k}_{0}^{*}=\alpha / 3 \beta$ for a monopoly. Q.E.D.

\section{Proof of Proposition 2}

From Lemma $3, \mathrm{k}_{\mathrm{A} 1}{ }^{*}=\mathrm{k}_{\mathrm{A} 2}{ }^{*}=\alpha / 9 \beta \Rightarrow \mathrm{k}_{\mathrm{A} 1}{ }^{*}+\mathrm{k}_{\mathrm{A} 2}{ }^{*}=2 \alpha / 9 \beta$ for a duopoly. From Lemma 1 , $\mathrm{k}_{\mathrm{A}}{ }_{\mathrm{A}}=\alpha / 3 \beta$ for a monopoly. Q.E.D.

\section{$\underline{\text { Proof of Proposition } 3}$}


From Lemma 1, for a monopoly, $\mathrm{k}_{\mathrm{A}}^{*}=\alpha / 3 \beta$ and $\mathrm{k}_{0}{ }_{0}=\alpha / 3 \beta$, hence $\mathrm{k}_{\mathrm{A}}{ }^{*} /\left(\mathrm{k}_{0}{ }^{*}+\mathrm{k}_{\mathrm{A}}{ }^{*}\right)=1 / 2$. From Lemma 3, for duopoly, $\mathrm{k}_{\mathrm{Ai}}{ }^{*}=\alpha / 9 \beta$ and $\mathrm{k}_{0 \mathrm{i}}{ }^{*}=\alpha / 3 \beta$, hence $\mathrm{k}_{\mathrm{Ai}}{ }^{*} /\left(\mathrm{k}_{0 \mathrm{i}}{ }^{*}+\mathrm{k}_{\mathrm{Ai}}{ }^{*}\right)=1 / 4$. Q.E.D.

\section{Proof of Lemma 4}

Given that $\mathrm{P}_{\mathrm{AH}}=\alpha-\beta_{\mathrm{H}}\left(\mathrm{k}_{\mathrm{AH}}+\mathrm{k}_{\mathrm{AL}}+\mathrm{k}_{0 \mathrm{H}}+\mathrm{k}_{0 \mathrm{~L}}\right), \mathrm{P}_{0 \mathrm{H}}=\alpha-\beta_{\mathrm{H}}\left(\mathrm{k}_{0 \mathrm{H}}+\mathrm{k}_{0 \mathrm{~L}}\right), \mathrm{P}_{\mathrm{AL}}=\alpha-$ $\beta_{\mathrm{L}}\left(\mathrm{k}_{\mathrm{AH}}+\mathrm{k}_{\mathrm{AL}}+\mathrm{k}_{0 \mathrm{H}}+\mathrm{k}_{0 \mathrm{~L}}\right), \mathrm{P}_{0 \mathrm{~L}}=\alpha-\beta_{\mathrm{L}}\left(\mathrm{k}_{0 \mathrm{H}}+\mathrm{k}_{0 \mathrm{~L}}\right)$, then from objective function $(6), \pi_{\mathrm{H}}=(\alpha-$ $\left.\left.\beta_{\mathrm{H}}\left(\mathrm{k}_{\mathrm{AH}}+\mathrm{k}_{\mathrm{AL}}+\mathrm{k}_{0 \mathrm{H}}+\mathrm{k}_{0 \mathrm{~L}}\right)\right) \mathrm{k}_{\mathrm{AH}}+\left(\alpha-\beta_{\mathrm{H}}\left(\mathrm{k}_{0 \mathrm{H}^{+}}+\mathrm{k}_{0 \mathrm{~L}}\right)\right) \mathrm{k}_{0 \mathrm{H}}\right]-\mathrm{C} . \quad$ FOC: $\mathrm{k}_{\mathrm{AH}}=\left(\alpha-\beta_{\mathrm{H}} \mathrm{k}_{\mathrm{AL}}-\beta_{\mathrm{H}} \mathrm{k}_{\mathrm{OH}^{-}}\right.$ $\left.\beta_{\mathrm{H}} \mathrm{k}_{0 \mathrm{~L}}\right) / 2 \beta_{\mathrm{H}}$, and $\mathrm{k}_{\mathrm{AL}}=\left(\alpha-\beta_{\mathrm{L}} \mathrm{k}_{\mathrm{AH}}-\beta_{\mathrm{L}} \mathrm{k}_{0 \mathrm{~L}}-\beta_{\mathrm{L}} \mathrm{k}_{0 \mathrm{H}}\right) / 2 \beta_{\mathrm{L}}$, which imply that $\mathrm{k}_{\mathrm{AH}}{ }^{*} \mid \mathrm{k}_{0}=\left(2 \alpha \beta_{\mathrm{L}^{-}}\right.$ $\left.\alpha \beta_{\mathrm{H}}-\beta_{\mathrm{H}} \beta_{\mathrm{L}} \mathrm{k}_{0 \mathrm{~L}}-\beta_{\mathrm{H}} \beta_{\mathrm{L}} \mathrm{k}_{0 \mathrm{H}}\right) / 3 \beta_{\mathrm{H}} \beta_{\mathrm{L}}$ and $\mathrm{k}_{\mathrm{AL}}{ }^{*} \mid \mathrm{k}_{0}=\left(2 \alpha \beta_{\mathrm{H}}-\alpha \beta_{\mathrm{L}}-\beta_{\mathrm{L}} \beta_{\mathrm{H}} \mathrm{k}_{0 \mathrm{H}}-\beta_{\mathrm{L}} \beta_{\mathrm{H}} \mathrm{k}_{0 \mathrm{~L}}\right) / 3 \beta_{\mathrm{H}} \beta_{\mathrm{L}} . \pi_{0 \mathrm{H}}$ $=\left[\alpha-\beta_{\mathrm{H}}\left(\mathrm{k}_{0 \mathrm{H}}+\mathrm{k}_{0 \mathrm{~L}}\right)\right] \mathrm{k}_{0 \mathrm{H}} \Rightarrow$ FOC wrt $\mathrm{k}_{0 \mathrm{H}}: \mathrm{k}_{0 \mathrm{H}}=\left(\alpha-\beta_{\mathrm{H}} \mathrm{k}_{0 \mathrm{~L}}\right) / 2 \beta_{\mathrm{H}}$. Similarly, solve for firm $\mathrm{L}$ to get $\mathrm{k}_{0 \mathrm{~L}}=\left(\alpha-\beta_{\mathrm{L}} \mathrm{k}_{0 \mathrm{~L}}\right) / 2 \beta_{\mathrm{L}}$. Hence, $\mathrm{k}_{0 \mathrm{H}}{ }^{*}=\left(2 \alpha \beta_{\mathrm{L}}-\alpha \beta_{\mathrm{H}}\right) / 3 \beta_{\mathrm{H}} \beta_{\mathrm{L}}$ and $\mathrm{k}_{0 \mathrm{~L}}{ }^{*}=\left(2 \alpha \beta_{\mathrm{H}}-\alpha \beta_{\mathrm{L}}\right) / 3 \beta_{\mathrm{H}} \beta_{\mathrm{L}}$. Substitute $\mathrm{k}_{0 \mathrm{H}}{ }^{*}$ and $\mathrm{k}_{0 \mathrm{~L}}{ }^{*}$ into $\mathrm{k}_{\mathrm{AH}}{ }^{*} \mid \mathrm{k}_{0}$ and $\mathrm{k}_{\mathrm{AL}}{ }^{*} \mid \mathrm{k}_{0} \Rightarrow \mathrm{k}_{\mathrm{AH}}{ }^{*}=\left(5 \alpha \beta_{\mathrm{L}}-4 \alpha \beta_{\mathrm{H}}\right) / 9 \beta_{\mathrm{H}} \beta_{\mathrm{L}}$ and $\mathrm{k}_{\mathrm{AL}}{ }^{*}$ $=\left(5 \alpha \beta_{\mathrm{H}}-4 \alpha \beta_{\mathrm{L}}\right) / 9 \beta_{\mathrm{H}} \beta_{\mathrm{L}}$. Substitute $\mathrm{k}_{\mathrm{AH}}{ }^{*} \mathrm{k}_{\mathrm{AL}}{ }^{*} \mathrm{k}_{0 \mathrm{H}}{ }^{*} \mathrm{k}_{0 \mathrm{~L}}{ }^{*}$ into response functions at $\mathrm{t}_{\mathrm{A}}$ and $\mathrm{t}_{0}$ to obtain $\mathrm{P}_{\mathrm{AH}}{ }^{*}=\left(5 \alpha \beta_{\mathrm{L}}-4 \alpha \beta_{\mathrm{H}}\right) / 9 \beta_{\mathrm{L}}, \mathrm{P}_{\mathrm{AL}}{ }^{*}=\left(5 \alpha \beta_{\mathrm{H}}-4 \alpha \beta_{\mathrm{L}}\right) / 9 \beta_{\mathrm{H}}, \mathrm{P}_{0 \mathrm{~L}}{ }^{*}=\left[\left(2 \alpha \beta_{\mathrm{H}}-\alpha \beta_{\mathrm{L}}\right) / 3 \beta_{\mathrm{H}}\right.$, and $\mathrm{P}_{0 \mathrm{H}}{ }^{*}=\left[\left(2 \alpha \beta_{\mathrm{L}}-\alpha \beta_{\mathrm{H}}\right) / 3 \beta_{\mathrm{L}}\right.$. Hence, given solutions for optimal capacities and pricing, solve for $\pi_{\mathrm{H}}{ }^{*}=\left[\left(61 \alpha^{2}{\beta_{\mathrm{L}}}^{2}-76 \alpha^{2} \beta_{\mathrm{H}} \beta_{\mathrm{L}}+25 \alpha^{2}{\beta_{\mathrm{H}}}^{2}\right) /\left(81 \beta_{\mathrm{H}} \beta_{\mathrm{L}}^{2}\right)-\mathrm{C}\right]$ and $\pi_{\mathrm{L}}{ }^{*}=\left[\left(61 \alpha^{2} \beta_{\mathrm{H}}{ }^{2}-\right.\right.$ $\left.76 \alpha^{2} \beta_{H} \beta_{L}+25 \alpha^{2} \beta_{L}^{2}\right) /\left(81 \beta_{H}^{2} \beta_{L}\right)-$ C]. Q.E.D.

\section{Proof of Proposition 4}

Since $\beta_{\mathrm{L}}<\beta_{\mathrm{H}}$, Lemma 4 implies, $\mathrm{P}_{\mathrm{AH}}{ }^{*}=\left(5 \alpha \beta_{\mathrm{L}}-4 \alpha \beta_{\mathrm{H}}\right) / 9 \beta_{\mathrm{L}}<\mathrm{P}_{\mathrm{AL}}{ }^{*}=\left(5 \alpha \beta_{\mathrm{H}^{-}} 4 \alpha \beta_{\mathrm{L}}\right) / 9 \beta_{\mathrm{H}}$, and $\mathrm{P}_{0 \mathrm{H}}{ }^{*}=\left(2 \alpha \beta_{\mathrm{L}^{-}} \alpha \beta_{\mathrm{H}}\right) / 3 \beta_{\mathrm{L}}<\mathrm{P}_{0 \mathrm{~L}}{ }^{*}=\left(2 \alpha \beta_{\mathrm{H}^{-}} \alpha \beta_{\mathrm{L}}\right) / 3 \beta_{\mathrm{H}}$. Hence, $\left(\mathrm{P}_{0 \mathrm{H}}{ }^{*}-\mathrm{P}_{\mathrm{AH}}{ }^{*}\right)=\left[\left(2 \alpha \beta_{\mathrm{L}^{-}}\right.\right.$ $\left.\left.\left.\alpha \beta_{\mathrm{H}}\right) / 3 \beta_{\mathrm{L}}\right]-\left[\left(5 \alpha \beta_{\mathrm{L}}-4 \alpha \beta_{\mathrm{H}}\right) / 9 \beta_{\mathrm{L}}\right]=\left[\left(\alpha \beta_{\mathrm{L}}+\alpha \beta_{\mathrm{H}}\right)\right] /\left(9 \beta_{\mathrm{L}}\right)\right]$, and $\left(\mathrm{P}_{0 \mathrm{~L}}{ }^{*}-\mathrm{P}_{\mathrm{AL}}{ }^{*}\right)=\left[\left(2 \alpha \beta_{\mathrm{H}^{-}}\right.\right.$ $\left.\left.\left.\alpha \beta_{\mathrm{L}}\right) / 3 \beta_{\mathrm{H}}\right]-\left[\left(5 \alpha \beta_{\mathrm{H}}-4 \alpha \beta_{\mathrm{L}}\right) / 9 \beta_{\mathrm{H}}\right]=\left[\left(\alpha \beta_{\mathrm{L}}+\alpha \beta_{\mathrm{H}}\right)\right] /\left(9 \beta_{\mathrm{L}}\right)\right]$. Q.E.D. 


\section{Proof of Proposition 5}

As $\beta_{\mathrm{L}}<\beta_{\mathrm{H}}$, Lemma 4 implies, $\mathrm{k}_{\mathrm{AH}}{ }^{*}=\left(5 \alpha \beta_{\mathrm{L}}-4 \alpha \beta_{\mathrm{H}}\right) / 9 \beta_{\mathrm{H}} \beta_{\mathrm{L}}<\mathrm{k}_{\mathrm{AL}}{ }^{*}=\left(5 \alpha \beta_{\mathrm{H}}-4 \alpha \beta_{\mathrm{L}}\right) / 9 \beta_{\mathrm{H}} \beta_{\mathrm{L}}$, and $\mathrm{k}_{0 \mathrm{H}}{ }^{*}=\left(2 \alpha \beta_{\mathrm{L}}-\alpha \beta_{\mathrm{H}}\right) / 3 \beta_{\mathrm{H}} \beta_{\mathrm{L}}<\mathrm{k}_{0 \mathrm{~L}}{ }^{*}=\left(2 \alpha \beta_{\mathrm{H}}-\alpha \beta_{\mathrm{L}}\right) / 3 \beta_{\mathrm{H}} \beta_{\mathrm{L}}$. As $\mathrm{k}_{\mathrm{AH}}{ }^{*}=\left(5 \alpha \beta_{\mathrm{L}}-4 \alpha \beta_{\mathrm{H}}\right) / 9 \beta_{\mathrm{H}} \beta_{\mathrm{L}}$ and $\mathrm{k}_{0 \mathrm{H}}{ }^{*}=\left(2 \alpha \beta_{\mathrm{L}}-\alpha \beta_{\mathrm{H}}\right) / 3 \beta_{\mathrm{H}} \beta_{\mathrm{L}}$, then $\mathrm{k}_{\mathrm{AH}}{ }^{*} / \mathrm{k}_{0 \mathrm{H}}{ }^{*}=\left(5 \alpha \beta_{\mathrm{L}}-4 \alpha \beta_{\mathrm{H}}\right) /\left(6 \alpha \beta_{\mathrm{L}}-3 \alpha \beta_{\mathrm{H}}\right) \Rightarrow$ $\partial\left(\mathrm{k}_{\mathrm{AH}}{ }^{*} / \mathrm{k}_{0 \mathrm{H}}{ }^{*}\right) / \partial \beta_{\mathrm{H}}=-9 \beta_{\mathrm{L}} /\left(6 \beta_{\mathrm{L}}-3 \beta_{\mathrm{H}}\right)^{2}<0$. Similarly, it can be shown that $\partial\left(\mathrm{k}_{\mathrm{AL}}{ }^{*} / \mathrm{k}_{0 \mathrm{~L}}{ }^{*}\right) / \partial \beta_{\mathrm{L}}$ $<0$. Q.E.D.

\section{Proof of Proposition 6}

From Lemma $4, \mathrm{k}_{\mathrm{AH}}{ }^{*}=\left(5 \alpha \beta_{\mathrm{L}}-4 \alpha \beta_{\mathrm{H}}\right) / 9 \beta_{\mathrm{H}} \beta_{\mathrm{L}} \rightarrow 0$, as $\beta_{\mathrm{H}} \rightarrow 5 \beta_{\mathrm{L}} / 4$. Q.E.D. 